\title{
Protozoa involved in butyric rather than lactic fermentative pattern during latent acidosis in sheep
}

\author{
Ludovic BROSSARD $^{\mathrm{a}, \mathrm{b}}$, Cécile MARTIN ${ }^{\mathrm{a} *}$, Frédérique CHAUCHEYRAS-DURAND ${ }^{\mathrm{b}, \mathrm{c}}$, \\ the late Brigitte MICHALET-DOREAU ${ }^{\mathrm{a}}$
}

\author{
a Unité de Recherches sur les Herbivores, INRA, Centre de Recherche de Clermont-Ferrand-Theix, \\ 63122 Saint-Genès-Champanelle, France \\ b Lallemand Animal Nutrition, 19 rue des Briquetiers, BP 59, 31702 Blagnac Cedex, France \\ ${ }^{\mathrm{c}}$ Laboratoire de Microbiologie, INRA, Centre de Recherche de Clermont-Ferrand-Theix, \\ 63122 Saint-Genès-Champanelle, France
}

(Received 5 November 2003; accepted 13 February 2004)

\begin{abstract}
We used six ruminally cannulated Texel wethers to study the relative role of protozoa and lactate-metabolizing bacteria in ruminal fermentative patterns during an induced latent acidosis. The sheep were fed an alfalfa hay $\operatorname{diet}(\mathrm{H})$ and latent acidosis was induced, following a short transition period of one week, with a grain-rich acidotic diet (W, $60 \%$ wheat $+40 \%$ alfalfa hay). Ruminal $\mathrm{pH}$, ruminal volatile fatty acids (VFA), lactate and $\mathrm{NH}_{3}$ concentrations, protozoa and lactate-utilizing bacterial counts, the relative proportions of three main bacteria implicated in lactate metabolism (a lactate-producing species, Streptococcus bovis, and two lactate-utilizing species, Selenomonas ruminantium, and Megasphaera elsdenii) using specific 16S-rRNA-targeting oligonucleotide probes, and lactate dehydrogenase (LDH) activity were determined for both diets. The $\mathrm{pH}$ parameters (mean, minimum, maximum, time and area under $\mathrm{pH} 6.0$ and 5.5) measured with the W diet were indicative of a latent (i.e., subacute and maintained) acidosis. However, a butyric rather than lactic latent acidosis was observed in this study. Total ruminal lactate concentration remained at low levels with the acidotic diet $\left(<4 \mathrm{mmol} \cdot \mathrm{L}^{-1}\right)$, but changes were observed in VFA composition, which was oriented towards butyrate at the expense of acetate $(P<0.05)$, while propionate remained constant. In agreement with the low ruminal lactate concentration, no changes in the proportion of $S$. bovis 16S-rRNA were observed. The lactate-metabolizing bacterial population also remained fairly constant in number, proportion and activity. The increase in butyrate concentration was accompanied by a proliferation of entodiniomorphs $(P<0.01)$. These results suggest that the protozoa limited lactate accumulation and possibly also the decrease in $\mathrm{pH}$ during latent acidosis. Experiments with defaunated and faunated sheep could provide further evidence of the role of protozoa in the development of rumen latent acidosis.
\end{abstract}

acidosis / rumen fermentation / protozoa / bacteria / lactate

\section{INTRODUCTION}

Acute acidosis in ruminants results from an excessive consumption of readily fer- mentable carbohydrates (RFC), causing a marked fall in ruminal $\mathrm{pH}$ below 5.0 [1]. In such acute cases of this nutritional disorder, lactic acid, as an end product of ruminal

* Corresponding author: cecile@clermont.inra.fr 
microbial fermentation, plays a key role [2]. After a first stage of high VFA production at $\mathrm{pH}>6$, lactate becomes a major fermentative product at a lower $\mathrm{pH}$ [3]. As the $\mathrm{pH}$ falls, lactate-producing microorganisms (Streptococcus bovis) outnumber the lactateutilizing microorganisms (Megasphaera elsdenii and Selenomonas ruminantium) [4]. Protozoa also disappear, and bacterial diversity is largely reduced [5]. If the $\mathrm{pH}$ continues to fall, lactobacilli replace $S$. bovis, initiating a spiraling effect with excessive lactate accumulation [6].

Acute acidosis, although very well known, is now rare whereas latent acidosis, defined as a subacute and maintained acidosis, is more discrete but affects a greater number of animals. However, latent acidosis is not so well characterized, because of its less drastic decrease in ruminal $\mathrm{pH}$ and its more variable fermentative patterns (ranging amounts of lactate, increased proportions of propionate and/or butyrate) [7-9]. This unstable state may reflect the oscillatory behavior of the ruminal microbial population in response to diet-based fermentative changes. Studies of ruminal microbial changes during latent acidosis [8] or adaptation to high concentrate diets [10-13] highlight the importance of equilibrium between lactate-producing and -utilizing microorganisms (both bacteria, protozoa) in the control of $\mathrm{pH}$ and lactate concentration.

The objective of the present study was to assess changes in protozoal populations and in bacteria involved in lactate metabolism during induced latent acidosis in sheep to determine their relative roles in ruminal fermentative patterns.

\section{MATERIALS AND METHODS}

\subsection{Animals, diets and experimental design}

Texel wethers ( $n=6,2$ years of age) with an average BW of $58.9 \pm 1.1 \mathrm{~kg}$ at the start of the experiment were used. Each animal was fitted with a ruminal cannula (i.d. $62 \mathrm{~mm}$ ) made of polyamide and polyvinyl chloride (Synthesia, Nogent-sur-Marne, France). Surgery was performed in a sterile environment under general anesthesia (Halothane, ICIU Pharma-vétérinaire, Paris, France) and under the responsibility of a licensed veterinarian with specialized training in large animal surgery. Surgical preparation of the wethers was carried out three months before the start of the study, during which time they received a hay-only diet. Throughout the experimental period, the animals were housed in individual stalls $(1.00 \times 1.50 \mathrm{~m})$ with automatic waterers and individual feed-bunks, and had free access to mineralized salt blocks (Na 38\%, Zn 0.9\%, Mn 0.075\%, Cu 0.15\%, I $0.009 \%$, and Co $0.0003 \%$ ).

For the duration of the study, the animals were fed two equal portions at 0800 and 2000, of two different diets: a forage diet $(\mathrm{H}$ diet) composed of $100 \%$ chopped alfalfa hay, and a wheat rich diet (W diet) composed of $60 \%$ pelleted ground wheat $(3-\mathrm{mm}$ screen) and $40 \%$ alfalfa hay. The chemical composition of the experimental feeds and diets is given in Table I. The two diets were offered according to the following experimental feeding design: the $\mathrm{H}$ diet was fed ad libitum for a 3-week adaptation period (weeks 1 to 3 ). From week 4, the animals were fed $90 \%$ of the maximum ad libitum $\mathrm{H}$ diet intake (i.e. $1.1 \mathrm{~kg}$ of DM per day) to ensure that the diet was ingested quickly and without refusals. The $\mathrm{H}$ diet was offered for two more weeks (weeks 4 and 5). The incorporation of wheat in the ration was then progressive $\left(10 \% \cdot \mathrm{d}^{-1}\right.$ during 6 days $)$ to reach the final acidotic $\mathrm{W}$ diet containing $60 \%$ of wheat and $40 \%$ of hay (week 6 ). The animals were maintained on the $\mathrm{W}$ diet for one week (week 7). The total duration of the experiment was 7 weeks, with two sampling periods of one week on weeks 5 and 7 .

\subsection{Ruminal $\mathrm{pH}$, sample collection and ruminal fermentative parameters}

Ruminal pH was measured continuously on seven consecutive days during each sampling period [14]. Each wether was fitted 
Table I. Chemical composition of experimental feeds and diets (\% DM).

\begin{tabular}{|c|c|c|c|c|}
\hline \multirow{3}{*}{ Item } & \multicolumn{2}{|c|}{ Feed } & \multicolumn{2}{|r|}{ Diet } \\
\hline & Alfalfa hay & Wheat & $\mathrm{H}$ & $\mathrm{W}$ \\
\hline & & & 100\% Hay & $60 \%$ Wheat $+40 \%$ Hay \\
\hline Organic matter & 91.2 & 97.2 & 91.2 & 94.8 \\
\hline Crude protein & 14.7 & 11.9 & 14.7 & 13.0 \\
\hline NDF & 45.2 & 15.8 & 45.2 & 27.6 \\
\hline $\mathrm{ADF}$ & 32.8 & 2.6 & 32.8 & 14.6 \\
\hline Starch & 0 & 67.9 & 0 & 40.7 \\
\hline
\end{tabular}

with an indwelling $\mathrm{pH}$ probe in the rumen connected to a data logger, which monitored the $\mathrm{pH}$ at 5-min intervals. The following parameters were calculated for each day using the $\mathrm{pH}$ kinetics obtained with the indwelling probes: mean, minimum and maximum $\mathrm{pH}$, time and area under $\mathrm{pH} 6.0$, and time and area under $\mathrm{pH}$ 5.5. The calculation of the area under the $\mathrm{pH}$ threshold $(6.0$ and 5.5) was the difference between these $\mathrm{pH}$ thresholds and the $\mathrm{pH}$ value multiplied by the time interval (i.e. $5 \mathrm{~min}$ ). The positive values (negative values reflect $\mathrm{pH}$ greater than the set $\mathrm{pH}$ threshold) were summed.

During each of the two sampling periods, ruminal liquid samples $(250 \mathrm{~mL})$ were taken manually from the ventral bag of the rumen via the cannula using a suction pump and a rigid plastic tube (length $400 \mathrm{~mm}$; i.d. $15 \mathrm{~mm})$, on two sampling times, before $(-1 \mathrm{~h})$ and after the morning meal $(+3 \mathrm{~h})$, on two sampling days (days 5 and 7), with a oneday interval to avoid any disturbance of ruminal function. The samples were immediately strained through a $250-\mu$ m nylon filter and the filtrate was used for analyses.

VFA and $\mathrm{NH}_{3}$ contents were respectively determined by gas chromatography using 4-methylvaleric acid as the internal standard (GC 8000 gas chromatograph, Carlo Erba Instrument, Milan, Italy) [15], and by a colorimetric method [16] at the two sampling times on $8 \mathrm{~mL}$ of filtrate preserved in duplicate by adding $0.8 \mathrm{~mL}$ of $5 \%$ (vol/vol) orthophosphoric acid. D- and Llactic acid content was determined using an enzymatic method on a further 8-mL aliquot (D-/L-lactic acid, Boehringer Mannheim 1112821, Roche Diagnostics, Meylan, France).

\subsection{Microbiological analysis}

Protozoa were counted at the two sampling times using a Dolfuss cell (Elvetec Services, Clermont-Ferrand, France) according to the procedures described by Jouany and Senaud [17], on $9 \mathrm{~mL}$ of filtrate preserved at $4{ }^{\circ} \mathrm{C}$ with $1 \mathrm{~mL}$ of solution made up of $50 \%$ glycerol, $49 \%$ distilled water, and $1 \%$ glutaraldehyde. Counting was performed during the month following the end of the experiment. Protozoa were further categorized as either entodiniomorphid or isotrichid holotrich ciliates by skeletal plate-staining with Lugol solution.

Lactate-utilizing bacteria were counted for both sampling times by the following counting procedure: decimal dilutions of filtrate in an anaerobic dilution medium [18] were inoculated in triplicate in a lactate culture medium under anaerobic conditions and incubated at $39^{\circ} \mathrm{C}$ for 2 weeks at maximum. During incubation, bacterial growth was checked regularly by the turbidity of the medium compared with a non-inoculated control medium. The dilution medium (pH 6.8) contained $85 \%$ ( $\mathrm{vol} / \mathrm{vol}$ ) distilled water, $7.5 \%(\mathrm{vol} / \mathrm{vol})$ mineral solution I [18], $7.5 \%(\mathrm{vol} / \mathrm{vol})$ mineral solution II [18], $0.01 \%$ (vol/vol) Resazurine, $0.4 \%$ (wt/vol) $\mathrm{NaHCO}_{3}$ and $0.05 \%$ (wt/vol) cysteine $\mathrm{HCl}$. The lactate culture medium 
Table II. Oligonucleotide probes used in this trial.

\begin{tabular}{|c|c|c|c|c|}
\hline Target & Reference & Probes & Sequence $\left(5^{\prime}-3^{\prime}\right)$ & $\mathrm{Tw}^{\mathrm{a}}\left({ }^{\circ} \mathrm{C}\right)$ \\
\hline All organisms & $\begin{array}{c}\text { Pace et al. } \\
\text { [21] }\end{array}$ & S-*-UNIV-1392-a-A-15 & ACGGGCGGTGTGT(AG)C & 46 \\
\hline $\begin{array}{l}\text { Streptococcus } \\
\text { bovis }\end{array}$ & This study & & TCTACTAGTGAAGCAATTGCT & 46 \\
\hline $\begin{array}{l}\text { Selenomonas } \\
\text { ruminantium }\end{array}$ & This study & & GACAGTTTCAATCCCATCACGGGGT & 52.5 \\
\hline $\begin{array}{l}\text { Megasphaera } \\
\text { elsdenii }\end{array}$ & This study & & CGGTCCCCTGACGGGGTTAA & 56 \\
\hline
\end{tabular}

(pH 6.8) contained 45\% (vol/vol) distilled water, $40 \%$ (vol/vol) clarified rumen fluid, $7.5 \%(\mathrm{vol} / \mathrm{vol})$ mineral solution I [18], $7.5 \%$ (vol/vol) mineral solution II [18], $1 \%$ (vol/vol) D-/L-lactic acid (Sigma L1893, Saint-Quentin Fallavier, France), $0.01 \%$ ( $\mathrm{vol} / \mathrm{vol}$ ) Resazurine, $0.5 \%$ (wt/vol) $\mathrm{NaHCO}_{3}$ and $0.05 \%$ (wt/vol) cysteine $\mathrm{HCl}$. After incubation, a significant bacterial growth, and the consumption of at least $50 \%$ of D-/ L-lactic acid in the medium, showed the presence of an efficient lactate-utilizing flora. D-/L-lactic acid content was assayed using an enzymatic method (D-/L-lactic acid, Boehringer Mannheim 1112821, Roche Diagnostics, Meylan, France). The most probable number (MPN) of lactate-utilizing bacteria was determined from McGrady's tables [19].

The 16S-rRNA quantities of three bacterial lactate-metabolizing species, a lactate-producing species, Streptococcus bovis, and two lactate-utilizing species, Selenomonas ruminantium, and Megasphaera elsdenii, were determined $(+3 \mathrm{~h}$ from morning feeding) from a freeze-dried part of filtrate $(100 \mathrm{~mL})$ using specific 16S-rRNA-targeting oligonucleotide probes. Total RNA was extracted from $50 \mathrm{mg}$ of freeze-dried sample, according to Chomczynski and Sacchi [20]. RNA extracts were blotted on nylon membranes (Hybond N+, Amersham Pharmacia Biotech, Saclay, France) using a dotblot apparatus (Schleicher and Schuell Co.,
Dassel, Germany). Hybridization was conducted using synthetic HPLC-purified oligonucleotide probes (MWG Biotech, Courtaboeuf, France) 5'end-labeled with ${ }^{32} \mathrm{P}$ using a T4 kinase (QBIOgene, Illkirch, France). Four $\gamma^{32} \mathrm{P}$-labeled oligonucleotide probes were used: the S-*-UNIV-1392-aA-15 probe targeting all organisms, and one probe for each of the three selected species (Tab. II). Except for the "Univ" probe, oligonucleotide probes were designed and validated in the laboratory (Millet, unpublished data) using RNA extracted from pure cultures of $S$. bovis DSM 20480, M. elsdenii DSM 20460 and S. ruminantium DSM 2872 and RNA extracted from sheep rumen fluid samples inoculated with different concentrations of each bacterial species $\left(10^{7}\right.$ to $10^{9}$ bacteria $\cdot \mathrm{mL}^{-1}$ of rumen fluid) alone or in combination. The temperatures used for the stringent washes are also shown in Table II. Total RNA (100, 75 and $50 \mathrm{ng}$ ) from pure cultures of S. bovis DSM 20480, M. elsdenii DSM 20460, S. ruminantium DSM 2872 and 16S-rRNA from E. coli (universal standard, Roche Diagnostics, Meylan, France) were used as controls. Radioactivity associated with hybridization signals was detected with a STORM instrument (Molecular Dynamics, Bondoufle, France). Bound probe was quantified by Image Quant software (Molecular Dynamics). The proportions of each species 16S-rRNA 
Table III. Daily ruminal $\mathrm{pH}$ parameters in sheep fed a control hay diet $(\mathrm{H})$ and a high-wheat diet $(\mathrm{W})$ inducing a latent acidosis $(n=6)$.

\begin{tabular}{|c|c|c|c|c|}
\hline \multirow{3}{*}{ Item } & \multicolumn{2}{|r|}{ Diet } & \multirow{3}{*}{ SE } & \multirow{3}{*}{ Diet effect } \\
\hline & $\mathrm{H}$ & $\mathrm{W}$ & & \\
\hline & 100\% Hay & $60 \%$ Wheat $+40 \%$ Hay & & \\
\hline Mean & 6.69 & 5.85 & 0.055 & $* * *$ \\
\hline Minimum & 6.41 & 5.34 & 0.073 & $* * *$ \\
\hline Maximum & 7.03 & 6.57 & 0.034 & $* * *$ \\
\hline Time under $6.0(\mathrm{~h})$ & 0.0 & 15.8 & 0.82 & $* * *$ \\
\hline Area under $6.0(\mathrm{pH} \times \mathrm{h})$ & 0.0 & 6.0 & 0.78 & $* *$ \\
\hline Time under $5.5(\mathrm{~h})$ & 0.0 & 3.9 & 0.83 & * \\
\hline Area under $5.5(\mathrm{pH} \times \mathrm{h})$ & 0.0 & 1.2 & 0.47 & NS \\
\hline
\end{tabular}

NS: non-significant $(P>0.1)$; $P<0.1 ; * P<0.05$; ** $P<0.01$; *** $P<0.001$.

were expressed as percentages of the total rRNA signal.

LDH enzyme activity of the ruminal liquid was measured at the two sampling times as follows: $40 \mathrm{~mL}$ of filtrate was immediately sonicated $(30 \%$ duty cycle, $200 \mathrm{~W}$, $4{ }^{\circ} \mathrm{C}, 16 \mathrm{~min}$ divided into eight 2 -min periods of sonication with 2-min intervals; Labsonic U, B Braun Biotech Inc, Bethelem, PA, USA). Unbroken cell material was removed by centrifugation $(15000 \mathrm{~g}, 15 \mathrm{~min}$, $4{ }^{\circ} \mathrm{C}$ ) and the supernatant material was used to estimate LDH activity. Enzyme preparations were stored for one day at $-80^{\circ} \mathrm{C}$ before assay. LDH activity was measured spectrophotometrically $\left(\mathrm{OD}_{340}\right)$ (U2000 Spectrophotometer, Hitachi, B. Braun Science Tec, Les Ulis, France) by following the disappearance of NADH at $39^{\circ} \mathrm{C}$. The reaction mixture $(3 \mathrm{~mL})$ contained buffer $(\mathrm{pH} 6.5$, triethanolamine- $\mathrm{HCl} 50 \mathrm{mM}$, EDTA $5 \mathrm{mM}$ ), $7 \mathrm{mM}$ NADH, $8 \mathrm{mM}$ Na-pyruvate, and $15 \mu \mathrm{L}$ of cell extract. The $8 \mathrm{mM}$ pyruvate concentration had been tested in a preexperiment as the optimal concentration for measuring LDH activity in these conditions. All assays were performed in triplicate $(n=3)$. The protein content of the enzyme preparations was determined according to Pierce and Suelter [22] using BSA as the standard.

\subsection{Statistical analyses}

Variance of the data was analyzed at each sampling time using the GLM procedure of SAS [23]. The model was

$$
Y_{i j}=\mu+D_{i}+A_{j}+E_{i j},
$$

where $Y_{i j}$ was the dependent variable for diet $i$ ( $i=1$ to 2 ), for animal $j(j=1$ to 6$) ; \mu$ was the population mean for the variable and $E_{i j}$ was a random error associated with the observation $i j$. In this study, period and diet effects were confounded. However, since the animals were physiologically stable (adult, non-productive), restricted-fed and maintained in a controlled environment, the period effect was assumed to be negligible. The diet effect was tested. Diet means were considered to differ if $P<0.05$, and a tendency to differ was considered to exist if $0.05<P<0.1$.

\section{RESULTS}

\subsection{Ruminal $\mathrm{pH}$ and fermentative parameters}

The mean, minimum and maximum ruminal $\mathrm{pH}$ values were lower with the $\mathrm{W}$ than with the $\mathrm{H}$ diet $(P<0.001$; Tab. III). The time under $\mathrm{pH} 6.0$ and under $\mathrm{pH} 5.5$ 
Table IV. Ruminal VFA composition, lactate and ammonia concentrations in sheep fed a control hay $\operatorname{diet}(\mathrm{H})$ and a high-wheat diet $(\mathrm{W})$ inducing a latent acidosis $(n=6)$.

\begin{tabular}{|c|c|c|c|c|c|}
\hline \multirow[b]{2}{*}{ Item } & \multirow[b]{2}{*}{$\begin{array}{l}\text { Time (h)/ } \\
\text { feeding }{ }^{\mathrm{a}}\end{array}$} & \multicolumn{2}{|r|}{ Diet } & \multirow[b]{2}{*}{ SE } & \multirow[b]{2}{*}{$\begin{array}{r}\text { Diet } \\
\text { effect }\end{array}$} \\
\hline & & $\begin{array}{c}\mathrm{H} \\
100 \% \text { Hay }\end{array}$ & $\begin{array}{c}\mathrm{W} \\
60 \% \text { Wheat }+40 \% \text { Hay }\end{array}$ & & \\
\hline Total VFA $\left(\mathrm{mmol} \cdot \mathrm{L}^{-1}\right)$ & $\begin{array}{l}-1 \\
+3\end{array}$ & $\begin{array}{c}85.1 \\
124.4\end{array}$ & $\begin{array}{l}102.2 \\
122.9\end{array}$ & $\begin{array}{c}4.99 \\
10.40\end{array}$ & $\begin{array}{c}\dagger \\
\mathrm{NS}\end{array}$ \\
\hline Acetate $(\mathrm{mol} \%)$ & $\begin{array}{l}-1 \\
+3\end{array}$ & $\begin{array}{l}70.5 \\
70.2\end{array}$ & $\begin{array}{l}65.0 \\
62.7\end{array}$ & $\begin{array}{l}1.17 \\
1.27\end{array}$ & $\begin{array}{l}* \\
* *\end{array}$ \\
\hline Propionate (mol \%) & $\begin{array}{l}-1 \\
+3\end{array}$ & $\begin{array}{l}16.6 \\
18.8\end{array}$ & $\begin{array}{l}18.5 \\
20.2\end{array}$ & $\begin{array}{l}1.04 \\
1.13\end{array}$ & $\begin{array}{l}\text { NS } \\
\text { NS }\end{array}$ \\
\hline Butyrate (mol \%) & $\begin{array}{l}-1 \\
+3\end{array}$ & $\begin{array}{l}7.4 \\
6.8\end{array}$ & $\begin{array}{l}11.7 \\
13.0\end{array}$ & $\begin{array}{l}1.06 \\
1.23\end{array}$ & $\begin{array}{l}* \\
*\end{array}$ \\
\hline Isobutyrate (mol \%) & $\begin{array}{l}-1 \\
+3\end{array}$ & $\begin{array}{l}1.8 \\
1.0\end{array}$ & $\begin{array}{l}1.2 \\
0.9\end{array}$ & $\begin{array}{l}1.10 \\
0.08\end{array}$ & $\begin{array}{c}* \\
\text { NS }\end{array}$ \\
\hline Valerate $(\mathrm{mol} \%)$ & $\begin{array}{l}-1 \\
+3\end{array}$ & $\begin{array}{l}0.9 \\
1.8\end{array}$ & $\begin{array}{l}1.0 \\
1.1\end{array}$ & $\begin{array}{l}0.07 \\
0.07\end{array}$ & $\begin{array}{l}\mathrm{NS} \\
* * *\end{array}$ \\
\hline Isovalerate ( $\mathrm{mol} \%)$ & $\begin{array}{l}-1 \\
+3\end{array}$ & $\begin{array}{l}2.5 \\
1.2\end{array}$ & $\begin{array}{l}2.2 \\
1.6\end{array}$ & $\begin{array}{l}0.17 \\
0.14\end{array}$ & $\begin{array}{l}\text { NS } \\
\text { NS }\end{array}$ \\
\hline Caproate (mol \%) & $\begin{array}{l}-1 \\
+3\end{array}$ & $\begin{array}{l}0.3 \\
0.2\end{array}$ & $\begin{array}{l}0.4 \\
0.6\end{array}$ & $\begin{array}{l}0.08 \\
0.18\end{array}$ & $\begin{array}{l}\text { NS } \\
\text { NS }\end{array}$ \\
\hline Acetate:propionate ratio & $\begin{array}{l}-1 \\
+3\end{array}$ & $\begin{array}{l}4.3 \\
3.8\end{array}$ & $\begin{array}{l}3.4 \\
3.3\end{array}$ & $\begin{array}{l}0.24 \\
0.20\end{array}$ & $\begin{array}{l}\text { NS } \\
\text { NS }\end{array}$ \\
\hline $\begin{array}{l}\text { Acetate:(propionate + } \\
\text { butyrate) }\end{array}$ & $\begin{array}{l}-1 \\
+3\end{array}$ & $\begin{array}{l}2.9 \\
2.7\end{array}$ & $\begin{array}{l}2.2 \\
1.9\end{array}$ & $\begin{array}{l}0.15 \\
0.13\end{array}$ & $\begin{array}{l}* \\
* *\end{array}$ \\
\hline Total lactate $\left(\mathrm{mmol} \cdot \mathrm{L}^{-1}\right)$ & $\begin{array}{l}-1 \\
+3\end{array}$ & $\begin{array}{l}0.84 \\
0.39\end{array}$ & $\begin{array}{l}1.18 \\
3.67\end{array}$ & $\begin{array}{l}0.113 \\
2.084\end{array}$ & $\stackrel{\dagger}{\dagger}$ \\
\hline L-Lactate $\left(\mathrm{mmol} \cdot \mathrm{L}^{-1}\right)$ & $\begin{array}{l}-1 \\
+3\end{array}$ & $\begin{array}{l}0.41 \\
0.17\end{array}$ & $\begin{array}{l}0.48 \\
1.49\end{array}$ & $\begin{array}{l}0.120 \\
0.877\end{array}$ & $\begin{array}{l}\text { NS } \\
\text { NS }\end{array}$ \\
\hline D-Lactate $\left(\mathrm{mmol} \cdot \mathrm{L}^{-1}\right)$ & $\begin{array}{l}-1 \\
+3\end{array}$ & $\begin{array}{l}0.44 \\
0.22\end{array}$ & $\begin{array}{l}0.70 \\
2.18\end{array}$ & $\begin{array}{l}0.069 \\
1.208\end{array}$ & $\begin{array}{c}* \\
\text { NS }\end{array}$ \\
\hline $\mathrm{NH}_{3}\left(\mathrm{mmol} \cdot \mathrm{L}^{-1}\right)$ & $\begin{array}{l}-1 \\
+3\end{array}$ & $\begin{array}{l}16.4 \\
19.5\end{array}$ & $\begin{array}{l}12.4 \\
12.4\end{array}$ & $\begin{array}{l}1.14 \\
1.61\end{array}$ & $\begin{array}{l}* \\
*\end{array}$ \\
\hline
\end{tabular}

a Time (h) from morning feeding.

b NS: non-significant $(P>0.1) ; \dagger P<0.1 ; * P<0.05 ; * * P<0.01 ; * * * P<0.001$.

increased with the $\mathrm{W}$ diet compared with the $\mathrm{H}$ diet $(P<0.001$ and 0.05 , respectively), $\mathrm{pH}$ remaining for $3.9 \mathrm{~h}$ under $\mathrm{pH} 5.5$ and for $15.8 \mathrm{~h}$ under $\mathrm{pH} 6.0$ with the $\mathrm{W}$ diet vs. $0 \mathrm{~h}$ with the $\mathrm{H}$ diet. The area under $\mathrm{pH}$ 6.0 was higher with the $\mathrm{W}$ diet than with the $\mathrm{H}$ diet (6.0 vs. $0 \mathrm{pH} \times \mathrm{h}$, respectively; $P<$ 0.01 ) whereas the area under $\mathrm{pH} 5.5$ was not significantly affected by the diet.
The total ruminal VFA concentration tended to be higher before feeding with the $\mathrm{W}$ diet $\left(102.2 \mathrm{mmol} \cdot \mathrm{L}^{-1}\right)$ than with the $\mathrm{H}$ diet $\left(85.1 \mathrm{mmol} \cdot \mathrm{L}^{-1}\right)(P<0.1$; Tab. IV $)$, but it stayed constant between the two diets after the feeding. The molar proportion of acetate and the acetate:(propionate + butyrate) ratio were reduced with the $\mathrm{W}$ diet compared with the $\mathrm{H}$ diet, before $(P<0.05)$ 
Table V. Ruminal protozoa number in sheep fed a control hay diet $(\mathrm{H})$ and a high-wheat diet $(\mathrm{W})$ inducing a latent acidosis $(n=6)$.

\begin{tabular}{|c|c|c|c|c|c|}
\hline \multirow[b]{2}{*}{ Item } & \multirow[b]{2}{*}{$\begin{array}{l}\text { Time }(\mathrm{h}) / \\
\text { feeding }\end{array}$} & \multicolumn{2}{|r|}{ Diet } & \multirow[b]{2}{*}{ SE } & \multirow[b]{2}{*}{ Diet effect ${ }^{b}$} \\
\hline & & $\begin{array}{c}\mathrm{H} \\
100 \% \text { Hay }\end{array}$ & $\begin{array}{c}\mathrm{W} \\
60 \% \text { Wheat }+40 \% \text { Hay }\end{array}$ & & \\
\hline Total protozoa ${ }^{\mathrm{c}}\left(10^{3} \cdot \mathrm{mL}^{-1}\right)$ & $\begin{array}{l}-1 \\
+3\end{array}$ & $\begin{array}{l}119(5.04) \\
232(5.31)\end{array}$ & $\begin{array}{l}333(5.45) \\
345(5.45)\end{array}$ & $\begin{array}{l}24.7 \\
69.5\end{array}$ & $\begin{array}{l}* * \\
\text { NS }\end{array}$ \\
\hline Holotrichs $\left(10^{3} \cdot \mathrm{mL}^{-1}\right)$ & $\begin{array}{l}-1 \\
+3\end{array}$ & $\begin{array}{c}1.7(3.16) \\
51.9(4.56)\end{array}$ & $\begin{array}{c}9.1(3.76) \\
70.5(4.65)\end{array}$ & $\begin{array}{l}1.56 \\
21.62\end{array}$ & $\begin{array}{c}* \\
\mathrm{NS}\end{array}$ \\
\hline Entodiniomorphs $\left(10^{3} \cdot \mathrm{mL}^{-1}\right)$ & $\begin{array}{l}-1 \\
+3\end{array}$ & $\begin{array}{l}117(5.03) \\
180(5.19)\end{array}$ & $\begin{array}{l}323(5.44) \\
275(5.34)\end{array}$ & $\begin{array}{l}24.6 \\
58.6\end{array}$ & $\begin{array}{l}* * \\
\text { NS }\end{array}$ \\
\hline
\end{tabular}

a Time (h) from morning feeding.

b NS: non-significant $(P>0.1)$; $† P<0.1 ; * P<0.05$; ** $P<0.01$; *** $P<0.001$.

c Values in parentheses are the $\log _{10}$ transformations of the data.

and after feeding $(P<0.01)$. Before and after feeding, the molar proportion of butyrate was higher with the $\mathrm{W}$ diet than with the $\mathrm{H}$ diet $(P<0.05)$. Molar proportions of propionate, isovalerate and caproate, and the acetate:propionate ratio were not significantly affected by the diet. Compared with the $\mathrm{H}$ diet, the molar proportion of isobutyrate decreased before feeding with the $\mathrm{W} \operatorname{diet}(P<0.05)$, and the molar proportion of valerate decreased after feeding $(P<0.001)$.

The ruminal lactate concentration tended to be higher before feeding with the $\mathrm{W}$ diet than with the $\mathrm{H} \operatorname{diet}(P<0.1$; Tab. IV). D and L-lactate proportions were approximately 56 and $44 \%$, respectively. The ruminal ammonia concentration was lower with the $\mathrm{W}$ diet than with the $\mathrm{H}$ diet at both sampling times $(P<0.05)$.

\subsection{Microbiological parameters}

Compared with the $\mathrm{H}$ diet, the total protozoa count numerically increased with the $\mathrm{W}$ diet. This diet effect was significant only before feeding $(P<0.01$; Tab. V) and was mainly due to an increase in the numbers of entodiniomorphs, which made up the great majority (more than 97\%) of the protozoal population.
Lactate-utilizing bacterial counts showed a slight but non-significant increase with the $\mathrm{W}$ diet compared with the $\mathrm{H}$ diet (Tab. VI).

The total rRNA concentration and the relative 16S-rRNA proportion of $S$. bovis, a lactate-producing species, were not significantly modified by the acidotic diet. Concerning the lactate-utilizing species, there was a trend for the relative population size of $S$. ruminantium to be higher with the $\mathrm{W}$ diet than with the $\mathrm{H} \operatorname{diet}(P<0.1$; Tab. VI), whereas $M$. elsdenii 16S-rRNA was not detected in the rumen of the animals for either diet.

Neither total nor specific LDH activities differed between the diets before feeding (Tab. VII). After feeding these activities tended to be $50 \%$ lower with the $\mathrm{W}$ diet than with the $\mathrm{H} \operatorname{diet}(P<0.1)$.

\section{DISCUSSION}

The modifications of mean ruminal $\mathrm{pH}$, time and area values induced by the $\mathrm{W}$ diet agreed with those observed in a previous experiment on sheep fed a similar diet [14]. Several definitions of latent acidosis can be found in the literature, e.g., a mean daily $\mathrm{pH}$ 
Table VI. Rumen liquid bacterial populations in sheep fed a control hay diet $(\mathrm{H})$ and a high-wheat diet $(\mathrm{W})$ inducing a latent acidosis $(n=6)$.

\begin{tabular}{|c|c|c|c|c|c|}
\hline \multirow[b]{2}{*}{ Item } & \multirow[b]{2}{*}{$\begin{array}{l}\text { Time }(\mathrm{h}) / \\
\text { feeding }\end{array}$} & \multicolumn{2}{|r|}{ Diet } & \multirow[b]{2}{*}{ SE } & \multirow[b]{2}{*}{ Diet effect ${ }^{\mathrm{t}}$} \\
\hline & & $\begin{array}{c}\mathrm{H} \\
100 \% \text { Hay }\end{array}$ & $\begin{array}{c}\mathrm{W} \\
60 \% \text { Wheat }+40 \% \text { Hay }\end{array}$ & & \\
\hline Lactate-utilizing bacteria & -1 & $178(7.25)$ & $650(7.81)$ & 214.0 & NS \\
\hline Number ${ }^{\mathrm{c}}\left(10^{5} \cdot \mathrm{mL}^{-1}\right)$ & +3 & $239(7.38)$ & $1583(8.20)$ & 521.3 & NS \\
\hline Total rRNA $\left(\mu \mathrm{g} \cdot \mathrm{g}^{-1} \mathrm{DM}\right)$ & +3 & 1369 & 769 & 301.6 & NS \\
\hline $\begin{array}{l}\text { S. bovis rRNA } \\
\text { as \% of total rRNA }\end{array}$ & +3 & 0.12 & 0.21 & 0.052 & NS \\
\hline $\begin{array}{l}\text { M. elsdenii rRNA } \\
\text { as \% of total rRNA }\end{array}$ & +3 & $\mathrm{ND}^{\mathrm{d}}$ & ND & - & - \\
\hline $\begin{array}{l}\text { S. ruminantium rRNA } \\
\text { as } \% \text { of total rRNA }\end{array}$ & +3 & 0.09 & 0.75 & 0.143 & $\dagger$ \\
\hline
\end{tabular}

a Time (h) from morning feeding.

b NS: non-significant $(P>0.1) ; \dagger P<0.1 ; * P<0.05 ; * * P<0.01 ; * * * P<0.001$.

${ }^{c}$ Values in parentheses are the $\log _{10}$ transformations of the data.

d ND: not detected.

Table VII. Rumen liquid lactate dehydrogenase (LDH) activity in sheep fed a control hay diet (H) and a high-wheat diet $(\mathrm{W})$ inducing a latent acidosis $(n=6)$.

\begin{tabular}{lcccccc}
\hline & & \multicolumn{3}{c}{ Diet } & & \\
\cline { 3 - 4 } Item & $\begin{array}{c}\text { Time }(\mathrm{h}) / \\
\text { feeding }^{\mathrm{a}}\end{array}$ & $\begin{array}{c}\mathrm{H} \\
100 \% \text { Hay }\end{array}$ & $60 \%$ Wheat $+40 \%$ Hay & SE & Diet effect $^{\mathrm{b}}$ \\
\hline LDH total activity & -1 & 0.20 & 0.22 & & 0.037 & $\mathrm{NS}$ \\
$\left(\mu \mathrm{mol}\right.$ lactate $\left.\cdot \mathrm{min}^{-1} \cdot \mathrm{g}^{-1} \mathrm{DM}\right)$ & +3 & 0.15 & 0.08 & & 0.024 & $\dagger$ \\
LDH specific activity & -1 & 1.34 & 1.17 & & 0.226 & $\mathrm{NS}$ \\
$\left(\mu \mathrm{mol}\right.$ lactate $\cdot \mathrm{min}^{-1} \cdot \mathrm{g}^{-1}$ protein $)$ & +3 & 1.04 & 0.57 & & 0.154 & $\dagger$ \\
\hline
\end{tabular}

a Time (h) from morning feeding.

b NS: non-significant $(P>0.1) ; \uparrow P<0.1 ; * P<0.05 ; * * P<0.01 ; * * * P<0.001$.

between 6.25 and 5.5 [24], repeated bouts of depressed rumen $\mathrm{pH}$ between 5.2 and 5.6 [25], or between 5.0 and 5.5 [1]. Ruminal $\mathrm{pH}$ values observed in our study with the acidotic diet are consistent with these definitions and indicate that the animals were subjected to a latent, i.e. subacute and maintained, acidosis.

Total ruminal lactate concentration remained at low levels with the $\mathrm{W} \operatorname{diet}(<4 \mathrm{mM})$. Low concentration of ruminal lactate was also reported in sheep $[13,14]$ and in steers [7, 26] fed high starch diets ( $>40 \%$ on a DM basis). The total ruminal VFA concentration tended to increase with the $\mathrm{W}$ diet before feeding and stayed constant after feeding. Although nonsystematic [27], the introduction of RFC in the diet generally results in an increase in the total ruminal VFA concentration [4]. A higher post-prandial absorption rate of VFA with the $\mathrm{W}$ diet than with the $\mathrm{H}$ diet, related to the lower $\mathrm{pH}$, 
may explain the similar post-feeding VFA concentrations in the two diets [28]. The ruminal acetate proportion decreased with the $\mathrm{W}$ diet, while the propionate proportion was stable, and the butyrate proportion increased. In the literature, digestion of high starch diets gives different VFA fermentative profiles in the rumen. In vivo studies on ruminants fed diets containing 30 to $70 \%$ of starch report a decrease in the acetate proportion in favor of propionate [29, 30], butyrate [14, 31, 32], or both [8, 10, 12].

Ruminal $\mathrm{NH}_{3}$ concentration was lower with the $\mathrm{W}$ diet than with the $\mathrm{H}$ diet. This is in agreement with other studies on steers in subacute acidosis [8] or feeding an increasing proportion of concentrate [10, 11]. This could be explained by a greater microbial assimilation with the $\mathrm{W}$ diet than with the $\mathrm{H}$ diet.

The original approach of this work was to explain the butyric rather than lactic fermentative pattern during latent acidosis by changes in the microbial community. It may be supposed that lactate did not accumulate with the $\mathrm{W}$ diet because of a low production, or because of a balance between production and utilization by lactate-metabolizing microorganisms, and especially by bacteria. Since $S$. bovis, $S$. ruminantium and $M$. elsdenii are known to be the major bacterial species involved in ruminal lactate metabolism [33], we used specific oligonucleotide probes targeting 16S-rRNA of these bacteria in the rumen. This technique has been largely applied to ruminal cellulolytic bacteria [34-37], but to our knowledge, not to ruminal lactate-metabolizing bacteria. Considering the results obtained after feeding by the probe technique for $S$. ruminantium and those obtained at the same sampling time for lactate-utilizing bacterial counts, we observed that the proportion of 16S-rRNA specific for $S$. ruminantium relative to total rRNA was in agreement with the contribution of lactate-utilizing bacteria within the total ruminal bacterial population, known to range between $10^{9}$ to $10^{10}$ cells $\cdot \mathrm{mL}^{-1}$ [38].
The $S$. ruminantium 16 S-rRNA proportion tended to increase with the $\mathrm{W}$ diet. However, S. ruminantium is not an exclusive lactate-utilizing bacterium and can ferment other substrates if lactate is limiting [39]. M. elsdenii 16S-rRNA was not detectable in our study, suggesting that the population levels were below the detection limit of the technique used (approx. $10^{6}$ cells $\left.\cdot \mathrm{mL}^{-1}\right)$. This bacterium is usually responsible for metabolizing 60 to $80 \%$ of the lactate produced in the rumen [33]; this lack of detection may simply reflect the low concentration of lactate that could be used as the substrate by this bacterium. Concerning the lactate-producing bacteria, no diet effect was observed on the S. bovis 16SrRNA proportion. Mackie et al. [12] in sheep during the adaptation to a high concentrate diet, and Goad et al. [8] in steers in latent acidosis, observed no ruminal lactate accumulation with an increase of both lactate-producing and -utilizing bacteria populations when using classical enumeration techniques. In both studies, the increase of lactate-producing bacteria concerned Lactobacillus but not $S$. bovis. In a more recent study using a real-time Taq nuclease assay technique on high grain-fed steers [40], ruminal lactate did not accumulate either. The S. bovis population remained constant, but it was shown that the M. elsdenii population increased.

Total and specific LDH activity of liquid associated microorganisms, responsible for the conversion of pyruvate into lactate, was similar before feeding with both diets, and tended to be lower after feeding with the $\mathrm{W}$ diet, i.e., when ruminal $\mathrm{pH}$ was minimal (5.34). This was surprising since other authors [41] observed in vitro that the LDH activity of pure cultures of $S$. bovis or $S$. ruminantium increased when culture $\mathrm{pH}$ decreased. The low LDH activity found with the acidotic diet and the lack of changes observed in the lactate-producing and-utilizing bacteria indicate a low overall lactate production with the acidotic diet. 
Compared with the $\mathrm{H}$ diet, protozoal numbers were higher with the $\mathrm{W}$ diet. This was consistent with the fact that the protozoal population increases with the proportion of starch in the diet, up to a certain level above which the protozoa concentration decreases, sometimes until defaunation $[38,42]$. Protozoa can have several effects on ruminal fermentation. Entodiniomorphs, which represented $87 \%$ of the total protozoal population in the present study, engulf starch granules very rapidly [43] and thus compete effectively with amylolytic bacteria for their substrate [2]. In addition, starch is fermented by protozoa at a slower rate than in amylolytic bacteria and the main products of fermentation are VFA rather than lactate $[42,44]$. Thus they have a stabilizing effect in the rumen by delaying fermentation. Entodiniomorphs are also able to consume lactate and thus may play an essential role in the prevention of lactate accumulation [45, 46]. Moreover, entodiniomorphs could be involved in the fermentative pattern towards butyrate observed with the W diet. Indeed, they ferment starch preferentially to butyrate rather than to propionate $[44,47]$. On the contrary to our results, Goad et al. [8] observed a decrease in protozoa numbers in steers during latent acidosis. However, these different observations may result from the different ruminal $\mathrm{pH}$ conditions during the studies. Before feeding, the ruminal $\mathrm{pH}$ of the acidotic animals was lower in the study of Goad et al. [8] than in the present study (5.5 vs. 6.5, respectively). It can be supposed that the present study describes an earlier stage of latent acidosis and the study of Goad et al. [8] a later stage of latent acidosis.

Bacteria may also be involved in the fermentative pattern towards butyrate. M. elsdenii is a major producer of butyrate from lactate [48] but in this experiment, the level of this bacterium was too low to have a significant impact, as suggested by the results obtained with the 16S-rRNA targeted probes technique. Butyrivibrio fibrisolvens, a bacterium not examined in our study, is also a major butyrate-producing bacterium in the rumen
[39]. It has been shown to be predominant in sheep during adaptation to high concentrate diets [12], and so this species may also contribute to butyrate production in the present study.

\section{CONCLUSION}

The present study shows that a high starch acidotic diet induced a butyric rather than lactic latent acidosis. An increase in entodiniomorph protozoa numbers may have promoted butyrate production, restricted bacterial access to starch, and so limited ruminal lactate accumulation. It is suggested that protozoa may play a major role in preventing the development of acidosis by the direct and indirect control of ruminal fermentation and bacterial populations. However, other regulation mechanisms within the rumen are possible. The comparison between defaunated and faunated animals would clarify the role of ciliate protozoa during latent acidosis.

\section{ACKNOWLEDGMENTS}

The authors thank the personnel of the experimental unit for sampling and animal care, $\mathrm{M}$. Fabre for protozoa counting, Y. Rochette and L. Genestoux for chemical analyses, S. Masséglia for RNA-targeting probes and microbial enumerations, and Lallemand Animal Nutrition for financial support of this work.

\section{REFERENCES}

[1] Oetzel GR. Clinical aspects of ruminal acidosis in dairy cattle. In: Proc. 33rd Annual Conference, American Association of Bovine Practitioners, 2000, p 46-53.

[2] Owens FN, Secrist DS, Hill WJ, Gill DR. Acidosis in cattle: a review. J Anim Sci 1998, 76: 275-286.

[3] Slyter LL. Influence of acidosis on rumen function. J Anim Sci 1976, 43: 910-929.

[4] Nocek JE. Bovine acidosis: implications on laminitis. J Dairy Sci 1997, 80: 1005-1028. 
[5] Enemark JMD, Jorgensen RJ, Enemark PSt. Rumen acidosis with special emphasis on diagnostic aspects of subclinical rumen acidosis: a review. Vet Ir Zootech 2002, 20: 16-29.

[6] Russell JB, Hino T. Regulation of lactate production in Streptococcus bovis: a spiraling effect that contributes to rumen acidosis. J Dairy Sci 1985, 68: 1712-1721.

[7] Burrin DG, Britton RA. Response to monensin in cattle during subacute acidosis. J Anim Sci 1986, 63: 888-893.

[8] Goad DW, Goad CL, Nagaraja TG. Ruminal microbial and fermentative changes associated with experimentally induced subacute acidosis in steers. J Anim Sci 1998, 76: 234 241.

[9] Horn GW, Gordon JL, Prigge EC, Owens FN. Dietary buffers and ruminal and blood parameters of subclinical lactic acidosis in steers. $\mathrm{J}$ Anim Sci 1979, 48: 683-691.

[10] Coe ML, Nagaraja TG, Sun YD, Wallace N, Towne EG, Kemp KE, Hutcheson JP. Effect of virginiamycin on ruminal fermentation in cattle during adaptation to a high concentrate diet and during an induced acidosis. J Anim Sci 1999, 77: 2259-2268.

[11] Hristov AN, Ivan M, Rode LM, McAllister TA. Fermentation characteristics and ruminal ciliate protozoal populations in cattle fed medium- or high-concentrate barley-based diets. J Anim Sci 2001, 79: 515-524.

[12] Mackie RI, Gilchrist FMC. Changes in lactate-producing and lactate-utilizing bacteria in relation to $\mathrm{pH}$ in the rumen of sheep during stepwise adaptation to a high-concentrate diet. Appl Environ Microbiol 1979, 38: 422-433.

[13] Mackie RI, Gilchrist FMC, Roberts AM, Hannah PE, Schwartz HM. Microbiological and chemical changes in the rumen during the stepwise adaptation of sheep to high concentrate diets. J Agric Sci 1978, 90: 241-254.

[14] Brossard L, Martin C, Michalet-Doreau B. Ruminal fermentative parameters and blood acido-basic balance changes during onset and recovery of induced latent acidosis in sheep. Anim Res 2003, 52: 513-530.

[15] Jouany JP. Volatile fatty acids and alcohol determination in digestive contents, silage juices, bacterial cultures and anaerobic fermentor contents. Sci Aliments 1982, 2: 131144.

[16] Van Eenaeme CJ, Bienfait M, Lambot O, Pondant A. Détermination automatique de l'ammoniaque dans le liquide du rumen par la méthode de Berthelot adaptée à l'auto-analyzer. Ann Med Vet 1969, 7: 419-424.
[17] Jouany JP, Senaud J. Influence des ciliés du rumen sur la digestion des différents glucides chez les moutons. I. Utilisation des glucides pariétaux (cellulose, hemicellulose) et de l'amidon. Reprod Nutr Dev 1982, 22: 735752.

[18] Bryant MP, Burkey LA. Cultural methods and some characteristics of some of the more numerous groups of bacteria in the bovine rumen. J Dairy Sci 1953, 36: 205-217.

[19] Clarke KR, Owens NJP. A simple and versatile micro-computer program for the determination of "Most Probable Number". J Microbiol Methods 1983, 1: 133-137.

[20] Chomczynski P, Sacchi N. Single-step method of RNA isolation by acid-guanidium thiocyanate-phenol-chloroform extraction. Anal Biochem 1987, 162: 156-159.

[21] Pace NR, Stahl DA, Lane DJ, Olsen CJ. The use of rRNA sequences to characterize natural microbial populations. Adv Microbiol Ecol 1986, 9: 1-55.

[22] Pierce J, Suelter CH. An evaluation of coomassie brilliant blue G-250 dye-binding method for quantitative protein determination. Annal Biochem 1977, 81: 478-480.

[23] SAS. SAS/STAT ${ }^{\circledR}$ User's Guide: Statistics (Release 6.03). SAS Inst Inc, Cary, NC, 1988.

[24] Sauvant D, Meschy F, Mertens D. Les composantes de l'acidose ruminale et les effets acidogènes des rations. INRA Prod Anim 1999, 12: 49-60.

[25] Cooper R, Klopfenstein T. Effect of Rumensin and Feed Intake Variation on Ruminal $\mathrm{pH}$. Scientific Update on Rumensin/Tylan/Micotil for the Professional Feedlot Consultant. Elanco Animal Health, Greenfield, IN, 1996.

[26] Ghorbani GR, Morgavi DP, Beauchemin KA Leedle JAZ. Effects of bacterial direct-fed microbials on ruminal fermentation, blood variables, and the microbial populations of feedlot cattle. J Anim Sci 2002, 80: $1977-$ 1985.

[27] Krehbiel, CR, Britton RA, Harmon DL, Wester TJ, Stock RA. The effects of ruminal acidosis on volatile fatty acid absorption and plasma activities of pancreatic enzymes in lambs. J Anim Sci 1995, 73: 3111-3121.

[28] Dijkstra J, Boer H, van Bruchem J, Bruining $\mathrm{M}$, Tamminga $\mathrm{S}$. Absorption of volatile fatty acids from the rumen of lactating dairy cows as influenced by volatile fatty acid concentration, $\mathrm{pH}$, and rumen liquid volume. Br J Nutr 1993, 69: 385-396.

[29] Fulton WR, Klopfenstein TJ, Britton RA Adaptation to high concentrate diets by beef 
cattle. I. Adaptation to corn and wheat diets. J Anim Sci 1979, 49: 775-784.

[30] Lyle RR, Johnson RR, Wilhite JV, Backus WR. Ruminal characteristics in steers as affected by adaptation from forage to all-concentrate diets. J Anim Sci 1981, 53: 13831390.

[31] Doreau M, Ollier A, Michalet-Doreau B. Un cas atypique de fermentations ruminales associées à une cétose chez la vache en début de lactation. Rev Med Vet 2001, 152: 301-306.

[32] Eadie JM, Hyldgaard-Jensen J, Mann SO, Reid RS, Whitelaw FG. Observations on the microbiology and biochemistry of the rumen in cattle given different quantities of a pelleted barley ration. Br J Nutr 1970, 24: 157-177.

[33] Counotte GHM, Prins RA. Regulation of lactate metabolism in the rumen. Vet Res Commun 1981, 5: 101-115.

[34] Chaucheyras-Durand F, Fonty G. Establishment of cellulolytic bacteria and development of fermentative activities in the rumen of gnotobiotically-reared lambs receiving the microbial additive Saccharomyces cerevisiae CNCM I-1077. Reprod Nutr Dev 2001, 41: 57-68.

[35] Chen J, Weimer PJ. Competition among three predominant cellulolytic bacteria in the absence or presence of non-cellulolytic bacteria. Microbiology 2001, 147: 21-30.

[36] Martin C, Millet L, Fonty G, Michalet-Doreau B. Cereal supplementation modified the fibrolytic activity but not the structure of the cellulolytic community associated with rumen solid digesta. Reprod Nutr Dev 2001, 41: 413 424.

[37] Weimer PJ, Waghorn GC, Odt CL, Mertens DR. Effect of diet on populations of three species of ruminal cellulolytic bacteria in lactating dairy cows. J Dairy Sci 1999, 82: 122-134.

[38] Dehority BA, Orpin CG. Development of, and natural fluctuations in, rumen microbial populations. In: Hobson PN, Stewart CS (Eds.), The rumen microbial ecosystem, 2nd ed, Chapmann \& Hall, London, 1997, p 192-245.
[39] Stewart CS, Flint HJ, Bryant MP. The rumen bacteria. In: Hobson PN, Stewart CS (Eds), The rumen microbial ecosystem, 2nd ed, Chapmann \& Hall, London, 1997, p 10-72.

[40] Klieve AV, Hennessy D, Ouwerkerk D, Forster RJ, Mackie RI, Attwood GT. Establishing populations of Megasphaera elsdenii YE 34 and Butyrivibrio fibrisolvens YE 44 in the rumen of cattle fed high grain diets. J Appl Microbiol 2003, 95: 621-630.

[41] Asanuma N, Hino T. Tolerance to low pH and lactate production in rumen bacteria. Anim Sci Technol 1997, 68: 367-376.

[42] Bonhomme A. Rumen ciliates: their metabolism and relationships with bacteria and their hosts. Anim Feed Sci Technol 1990, 30: 203 266.

[43] Coleman G.S. The interrelationship between rumen ciliate protozoa and bacteria. In: Mc Donald IW, Warner ACI (Eds), Digestion and metabolism in the ruminant. Sydney, Australia, August 1974: Proc. 4th Int Symposium on Ruminant Physiology, University of New England Publishing Unit, Armidale, Australia, 1975, p 149-164.

[44] Abou Akkada AR, Howard BH. The biochemistry of rumen protozoa. III. The carbohydrate metabolism of Entodinium. Biochem J 1960, 76: 445-451.

[45] Newbold CJ, Williams AG, Chamberlain DG. The in-vitro metabolism of D,L-lactic acid by rumen microorganisms. J Sci Food Agri 1987, 38: 9-18.

[46] Nagaraja TG, Towne G, Beharka AA. Moderation of ruminal fermentation by ciliated protozoa in cattle fed a high-grain diet. Appl Environ Microbiol 1992, 58: 2410-2414.

[47] Williams AG, Coleman GS. The rumen protozoa. Springer-Verlag, New-York, 1992.

[48] Counotte GHM, Prins RA, Janssen RHA, DeBie MJA. Role of Megasphaera elsdenii in the fermentation of DL-[2-13C] lactate in the rumen of dairy cattle. Appl Environ Microbiol 1981, 42: 649-655. 